\title{
In the Shadow of Biological Warfare: Conspiracy Theories on the Origins of COVID-19 and Enhancing Global Governance of Biosafety as a Matter of Urgency
}

\author{
Jing-Bao Nie $(\mathbb{C}$
}

Received: 6 May 2020 / Accepted: 6 August 2020

(C) Journal of Bioethical Inquiry Pty Ltd. 2020

\begin{abstract}
Two theories on the origins of COVID-19 have been widely circulating in China and the West respectively, one blaming the United States and the other a highest-level biocontainment laboratory in $\mathrm{Wu}-$ han, the initial epicentre of the pandemic. Both theories make claims of biological warfare attempts. According to the available scientific evidence, these claims are groundless. However, like the episodes of biological warfare during the mid-twentieth century, the spread of these present-day conspiracy theories reflects a series of longstanding and damaging trends in the international scene which include deep mistrust, animosities, the power of ideologies such as nationalism, and the sacrifice of truth in propaganda campaigns. Also, the threats associated with biological warfare, bioterrorism, and the accidental leakage of deadly viruses from labs are real and growing. Thus, developing a better global governance of biosafety and biosecurity than exists at present is an urgent imperative for the international community in the broader context of a looming Cold War II. For such a governance, an ethical framework is proposed based upon the triple ethical values of transparency, trust, and the common good of humanity.
\end{abstract}

Keywords Origins of COVID-19 - Biosafety and biosecurity $\cdot$ Biological warfare $\cdot$ P4 or BSL-4 lab . China $\cdot$ USA $\cdot$ Global governance

J.-B. Nie $(\bowtie)$

Bioethics Centre, Otago Medical School, University of Otago, 60 Clyde Street, Dunedin 9056, New Zealand

e-mail: jing-bao.nie@otago.ac.nz
The devastating consequences of the COVID-19 pandemic for individuals, families, communities, countries, and the world as a whole offers vivid proof that microbes could be just as destructive and terrifying - if not more so-than the use of nuclear weapons. And it is much less difficult to forge biological weapons than nuclear ones. As a result, driven by their hunger for power and dominion, states and terrorist groups may feel increasingly tempted to access and exercise such super-biological means of destruction. Furthermore, the safety of the scientific laboratories where the most dangerous pathogens are researched (and sometimes created) has long been a sword of Damocles hanging over humankind.

Through examining two popular conspiracy theories on the origins of COVID-19 and the historical background of biological warfare (BW) during the midtwentieth century, this article will demonstrate the urgency of a much higher level of global governance of biosafety and biosecurity. Moreover, the key elements of an ethical framework for such a governance will be outlined.

\section{Conspiracy Theory Version 1: A P4 Lab in Wuhan}

In recent years, China has been investing heavily in strategically important sectors in science, technology, and biomedicine. A plan exists to establish half a dozen labs of the highest level of biocontainment, biosafety level-4 (BSL-4) or P4 (pathogen or protection level 4), in several cities. As a fruit of 
international cooperation primarily with France, the first BSL-4 lab was built at the Wuhan Institute of Virology (WIV) of the Chinese Academy of Science in 2017. When it became fully operational in 2018, authorities and scientists enthusiastically celebrated the lab as another landmark in science achieved by China, that is, in the typical spirit of patriotism or nationalism (Xinhua News 2018).

However, overseas experts were raising questions about the safety and even the necessity of such labs. Their concerns included the possible leakage of pathogens as well as the potential development of biological weapons (Cyranoski 2017). In 2018, U.S. intelligence also warned about the safety risks of the lab (Rogin 2020).

A few days after the lockdown of Wuhan in late January 2020, a U.S. newspaper prone to circulating conspiracy theories linked the origins of severe acute respiratory syndrome coronavirus 2 (SARS-Cov-2, then called 2019-nCoV) to China's covert biological weapons programme, citing an Israeli biological warfare expert (Gertz 2020). More sensationally, scientists from the Indian Institute of Technology published a preprint scientific paper where they reported their findings on four unique inserts of key structural proteins of HIV-1 in 2019-nCoV, a result which was "unlikely to be fortuitous in nature" (Pradhan et al. 2020). In other words, the novel coronavirus had been genetically engineered. Soon afterwards, the researchers withdrew their paper, citing a need for "re-analysing of the data."

Many Chinese also suspected a connection between the virus and the WIV. As a response, Shi Zhengli, an internationally known virologist at the WIV who discovered that the SARS virus originated in bats, posted in the Twitter-like Chinese social media platform Weiboa post which was reported in many media outlets:

The 2019-nCov is nature's punishment on the human race for uncivilized behaviour [i.e., eating wild animals]. I swear on my own life that the virus has no connection with the laboratory. To those people who believe in and are spreading the rumours perpetrated by third-rate media outlets, as well as believing in the unreliable "academic analysis" of Indian scholars, I would like to give this advice: Shut your dirty mouths!

Not surprisingly, this response has hardly helped to scotch the conspiracy theory, however understandable
Shi's indignation may have been. Scientific truth can never be guaranteed by swearing on one's own or anyone else's life but must be grounded on objective evidence. Asking people to "shut their mouths" can only be counterproductive when it comes to convincing them with sound theories and establishing trust and trustworthiness. Ideally, the final say on the issue should come from an independent party-in this case, Shi herself and the WIV itself have an obvious conflict of interest.

Mainstream scientific research and the more reputable mass media denounced the theory that the novel coronavirus had been genetically engineered or was a bioweapon (e.g., Andersen et al. 2020; Barclay 2020). Yet, the fact that the virus is not human-made does not necessarily excludes the possibility that the virus escaped the lab by accident (Field 2020; Guterl et al. 2020). This remains an open question; without independent and transparent investigations, it may never be either proven or disproven. The leakage of dangerous pathogens had already occurred more than once in other labs, as will be discussed in the fourth section of this paper.

China's official reaction has added fuel to the fires of suspicion. In mid-February, Chen Wei, a major general in the People's Liberation Army and a leading biological weapons expert at the Academy of Military Science, was appointed to take the helm at the WIV. In April, new rules were set in place for academic publications on COVID-19. In particular, studies of the origins of the novel coronavirus were to be subject to special scrutiny and official approval (Gan et al. 2020). Above all, supreme leader Xi Jinping, in order to "to strengthen areas of weakness and close the loopholes exposed by the epidemic," ordered the establishment of a law on biosecurity and the incorporation of biosecurity in the national security system (Xinhua News 2020). These remarks were taken by some commentators in the West as a tacit admission of the lab origins of SARS-CoV-2. Yet, in the Chinese context, they may also be interpreted as a way of lessening the risk of BW attacks by foreign countries.

\section{Conspiracy Theory Version 2: The United States}

Immediately after the epidemic (initially called "Wuhan pneumonia") became public knowledge in late January, an unsettling theory started to circulate in China. Posts with certain variations - but containing exactly the same 
information and similar wording — spread like wildfire, particularly on Chinese social media WeChat. They tied the origins of the virus to the first China-hosted international military multi-sport event which involved the participation of nearly ten thousand athletes from over one hundred countries.

The original message is a masterpiece of conspiracy theory rhetoric. It is worthwhile citing it in full (in English translation):

Compatriots: In this time of the Wuhan pneumonia epidemic, please do not forget the Seventh World Military Games in Wuhan three months ago. Of course, some international athletes came from Africa, where infectious diseases frequently break out. Some athletes came from the United States, which has long attempted to carry out biological warfare against China. When [the authorities] investigated the source of the virus responsible for the 2003 SARS epidemic, many clues pointed to the United States and its biological warfare conspiracy against China.

So, doesn't this coronavirus pneumonia outbreak in Wuhan have something to do with the USA? This outbreak coincides with respect to the timeline, coincides with respect to the place, and coincides with respect to the gathering of people. And it also coincides in a major way with the ChinaUS trade war, which is still raging fiercely. Shouldn't we put all these coincidences together to analyse, synthesize, theorize, and verify so as to reach a clear conclusion? While carrying out its trade war with China, the U.S. government took advantage of the Seventh World Military Games, where many American athletes had numerous personal interactions with Chinese, hiding the novel coronavirus in their equipment with the aim of infecting the people of Wuhan. As the virus has an incubation period of two or three months, outbreaks on a massive scale would occur around the Spring Festival Holiday when vast numbers of people return home for the Chinese New Year. In this way, the U.S. government plotted to utilize the novel coronavirus to carry out a devastating attack on the polity, economy, livelihoods, and people of New China so as to realize its evil goals of containing China's economy and thwarting the rise of New China. Do not forget: the United States is the best equipped country in BW materials, the country that most desires to contain
China's development, and the country that pushes hardest for its own interests.

Kind-hearted people of China, what is stopping us from seeing that it is the U.S. government that has been plotting behind the scenes and is the evil perpetrator of this coronavirus outbreak in $\mathrm{Wu}-$ han? Why should we falsely put the blame on a wild animal market? Please repost this item immediately so that more Chinese will know the truth. (WeChat Post)

Designed for social media, this post, along with its variations, presents a masterclass in disinformation writing in a number of ways. It revives an earlier conspiracy theory on the origins of the SARS epidemic in 2003 which has been circulating in China for years and received new attention after the outbreak of "Wuhan pneumonia." The anonymous document is built on and reinforces a fundamental historical narrative which emphasizes how, since the early nineteenth century, China has been humiliated by the Western powers through their imperialist and colonizing endeavours. It appeals to a long-rooted xenophobia, growing anti-United States and anti-Western sentiments, and China's dominant ideology of patriotism or nationalism. The theory implicitly but deftly exploits the fear of BW embedded in the historical memory of China as a victim of BW in the mid-twentieth century (see the next section). Forceful in tone, the post nevertheless appears to invite recipients to think about the issue and decide for themselves. Its author(s) is a master at manipulating the minds of its target audience, Chinese people. Little wonder that not only people in China but also many overseas Chinese have accepted the theory it presents - or at least do not consider it to be totally baseless.

This message uses a single stone to kill many birds. It responds to people's need for an answer about the origins of the novel coronavirus. Implicitly, but cleverly, it addresses the serious issue of accountability. The first official explanation linked the origins of then mysterious SARS-like pneumonia to the Huanan Seafood Wholesale Market, which was shut down in early January, three weeks before locking down the city of Wuhan. While the wet market theory still implies failures at the local level to prohibit the consumption and sale of wild animals, blaming a powerful foreign country for the origins of the pandemic effectively absolves China of all responsibility. 
No available scientific or other trustworthy evidence supports the claims made by this theory. However, it is evident that the authorities have been orchestrating this flow of disinformation. As WeChat is controlled and closely monitored by the government, the wide circulation of the above post and its variations on the social media platform would never have been possible without official endorsement or promotion. In March, without offering any evidence, the chief public health expert in China's national leadership against the epidemic, Zhong Nanshan, declared that "the first occurrence of Covid-19 in Wuhan does not mean it originated in Wuhan." Reported by Xinhua News (2018), this bold claim has been frequently cited as a scientific statement in the Chinese mass media and social media, receiving only scant criticism.

The theory of the U.S. origins of the virus serves a crucial role in a large-scale propaganda campaign aiming to define and reshape the metanarratives on the role of China in the world. According to the official discourse, due to the "strong leadership" of the Partygovernment and the "huge sacrifice" made by Chinese people, China has achieved "great success" in containing COVID-19. Such success becomes even more remarkable when compared to the inept response of most Western countries, particularly the United States. Above all, China's success "evidently" shows the superiority and global applicability of China's authoritarian response to COVID-19 as well as the Chinese political system (China's State Council Information Office 2020).

While the conspiracy theory is mostly targeted at Chinese, official attempts were made to advance it in the international community. In one case, utilizing Twitter (which is banned in China), Zhao Lijian, spokesperson and deputy director of the Information Department of the Ministry of Foreign Affairs, stated: "It might be the US army personnel which brought the epidemic to Wuhan." Such official remarks caused a crisis in ChinaU.S. relations (Myers 2020). A contextual factor is the Party-government's return to the Maoist totalitarian style of ruling in recent years, such as advancing the "philosophy of struggle" in foreign affairs and "wolf warrior diplomacy."

On the United States side, President Trump and members of his administration have called the virus "the China virus" on numerous occasions. The broader settings of the China-U.S. "fights" on the origins of COVID-19 lies in the rapidly deteriorating relations and even the looming "New Cold War" or "Cold War II" between the two nations, one existing superpower versus an emerging one.

\section{The Historical Context: The BW Episodes during the Mid-Twentieth Century}

How should bioethics respond to the conspiracy theories on the origins of COVID-19 or, more generally, the pandemic of disinformation and misinformation in the post-truth age? At least two tasks are involved: 1) to detect and address legitimate concerns - and differentiate them from groundless claims, and 2) to identify the sociopolitical and historical context in which certain conspiracy theories have thrived.

History often haunts the present in both predictable and unexpected ways. The wide spread of the two conspiracy theories presented above reflects a series of longstanding and damaging trends in the international scene which include deep mistrust, mutual animosities, the power of ideologies such as nationalism, and the sacrifice of truth in propaganda campaigns for political purposes. Identical or very similar political themes and ideological forces were manifested in the main episodes of BW in the mid-twentieth century.

China is so far the only nation whose people have suffered BW attacks. Prior to and during the Second World War, the Japanese Army established highly secret but extensive programmes of bacteriological warfare throughout China. The "secret of the secrets" in these "factories of death," such as the now-infamous Unit 731, was the barbaric experiments conducted by Japanese doctors and scientists upon thousands of living human beings, mostly Chinese nationals. In addition, biological weapons were deployed against both military and civilian targets in at least a dozen "large-scale field tests" throughout China. Hundreds of thousands of civilians died or suffered horribly from these human-made plagues (e.g. Harris 2002; Nie et al. 2009, 2010; Yang and Tam 2018).

After the Second World War, and with the (first) Cold War looming, the U.S. authorities made a secret deal with Japanese perpetrators, granting them immunity from war crimes prosecution. The purpose was to monopolize the scientific data gained through inhuman human experimentation so as to advance the United States' own BW programme (Harris 2002; Moreno 2001; Nie et al. 2010; Brody et al. 2014). While the 
Soviet Union tried to publicize internationally the overwhelming evidence from the Khabarovsk trial in the late 1940s, the public in the West was ignorant of Japan's BW crimes until the late 1980s or 1990s mainly because the U.S. authorities dismissed the trial as a "communist propaganda" (Nie 2004). For the sake or in the name of national interest and national security, the U.S. government trampled justice and morality underfoot and engaged in what the English common law tradition defines as "complicity after the fact." The U.S. government has never issued a public statement on its cover-up of Japan's wartime medical atrocities, let alone a public apology (Nie 2006; Devolder 2015).

China-U.S. conflict intensified during the Korean War (1950-1953). China, North Korea, and the Soviet Union accused the United States of Nie et al. 2009, 2010 employing bacteriological weapons against both military and civilian targets in Korea and China. An International Scientific Commission (1952) led by Joseph Needham - a prominent biologist in the United Kingdom who later became arguably the most influential China scholar in the West - confirmed the allegations. The United States denied the allegations. Because the commission's work was under the control of the North Korean and Chinese governments, the United States demanded more impartial investigations. The International Red Cross and the World Health Organization offered to convene a special commission, a move which was rejected by China and North Korea as a disguised attempt at espionage. A resolution on the matter was submitted to the United Nations by the United States and fifteen other countries but was blocked by the Soviet Union (Lederberg 1999).

The world may never know the truth about the issue of BW in the Korean War. Historians are still heatedly debating the subject. On one side of the debate, through examining declassified U.S., Canadian, and British documents, as well as materials in the Chinese Central Archives, Canadian scholars have presented strong evidence in support of the allegations (Endicott and Hagerman 1998). On the other side, research based on recently obtained memoirs of Chinese personnel involved and declassified documents from the Soviet Union has led to the conclusion that the allegations were "false, a grand piece of political theatre" (Leitenberg 2016).

Now, one wonders whether the world will never know the truth on the origins of SARS-Cov-2. It is very likely that this will be an issue for future historians to debate.

\section{Enhancing Global Governance of Biosafety and Biosecurity: A Matter of Urgency}

More robust global governance of biosafety and biosecurity is long overdue. Such a governance should include these three key areas: 1) a more effective ban on offensive BW programmes, 2) much improved prevention and preparation for bioterrorism, and 3) more transparent and routine surveillance of biological research labs (particularly P4 and P3 labs) in which scientists investigate the most dangerous pathogens such as the Ebola virus and the coronavirus.

In response to the horrors of the First World War, including the use of chemical weapons, the 1925 Geneva Protocol was created to ban the use of biological and chemical weapons. More significantly, the Biological Weapons Convention (BWC) began taking signatures in 1972 and entered into force in 1975 . Signed by most countries, it established an international milieu opposed to all forms of BW. However, as is widely recognized, the BWC, like many other international declarations and agreements, lacks compliance monitoring and verification mechanisms so that it is far from effective in controlling biological armament (see, e.g., Lederberg 1999; Guillemin 2005; Sims 2009).

From the mid-twentieth century, world powers including Japan, the United States, the United Kingdom, France, and the Soviet Union as well as other countries like Canada and South Africa have formulated clandestine, statesponsored schemes to harvest new knowledge in bacteriology and virology with the aim of devising and manufacturing biological weapons (see, e.g., Alibek and Handelman 1999; Mangold and Goldberg 1999; Harris and Paxman 2002; Miller et al. 2002; Guillemin 2005; Wheelis et al. 2006). Compared to nuclear bombs - the ultimate weapon of the twentieth century - which changed history forever, so far BW has not proved highly effective. Nevertheless, as a result of some remarkable discoveries and innovative tools in biology in recent decades, biological agents have the potential to become the ultimate weapon of the twenty-first century.

Biological weapons are "unfortunately characterized by low visibility, high potency, substantial accessibility, and relatively easy delivery" (Lederberg 1999, 9; see also Preston 2002). This can make them very tempting choices for not only states but terrorist groups or even individual terrorists. However, neither the international community nor any individual country is well prepared for bioterrorism. 
Safety issues of high-level biocontainment labs have long been raised. For instance, in August 2019, the U.S. government shut down its Army Medical Research Institute of Infectious Diseases in Fort Detrick due to safety concerns. The institute has been regarded as the top BWrelated research programme in the world (where the data of Japanese wartime human experimentation are stored). While no detailed information was given for the "national security" reason, the government determined that deadly germs and toxins would have "the potential to pose a severe threat to public, animal or plant health or to animal or plant products" (Grady 2019, II8). (In China, because the shutdown occurred just a few months before the initial outbreak of COVID-19 in Wuhan, this event has been treated as a piece of "strong evidence" for the theory on the U.S. origins of the novel coronavirus.) Almost two decades earlier, a microbiologist employed by the U.S. army institute had been a leading suspect, albeit never charged, for the anthrax mailings in 2001-bioterrorist attacks - that killed five people (ibid.).

Infections and even small-scale outbreaks associated with the escape of pathogens have already occurred in other labs as well. In China, for example, after the SARS epidemic in 2003, there was a small-scale outbreak in Anhui Province in 2004. A joint investigation by the Ministry of Health and the World Health Organization linked it to problems of biosafety management in a lab where the SARS virus was being researched (China Central Television 2004). Quite a few other accidents related to other biological labs have happened in other places in China in the past decades (Field 2020). While great progress in regulations and management of biosafety has been made in China in recent years (Yuan 2019), so far no evidence from independent investigation is available to assure the world that SARS-Cov-2 was totally disconnected to the relatively new PSL-4 lab in Wuhan.

It is, therefore, absolutely necessary and urgent that the international community takes coordinated actions to prevent any human-made pandemic. However there is no international organization, in the United Nations system or elsewhere, charged with overseeing biosafety and biosecurity at the global level (The Economist 2020).

Unfortunately, "Cold War II" is approaching, one between China and the United States, with willing and compelled allies on each side. Nationalist trends and other developments in global politics threaten international cooperation in the global governance of biosafety. Nevertheless, ironically, it is precisely because of these detrimental political and ideological forces that a higher form of global governance of biosafety and biosecurity is an urgent imperative.

\section{An Ethical Framework for the Common Good of Humanity}

Enhancing global oversight of biosafety and biosecurity needs new ethical visions. Any new structure must move beyond the sweeping ideologies like nationalism and the current practices dominated by secrecy, mistrust, and animosities. Here, an ethical framework is proposed, a framework that underlines the triple ethical values of transparency, trust, and trustworthiness, and the common good of humanity.

Secrecy is a salient and common feature in the history of state-sponsored BW programmes since the midtwentieth century. But, as widely recognized, transparency and openness are essential for public health and any ethical global governance. The ethical justifications for transparency include not only people's rights to know the truth but also the social utility it promotes. Furthermore, transparency nourishes and sustains trust. Transparency and openness may appear to cause distrust, especially when betray of trust is disclosed. But, although secrecy may result in a kind of false trust temporarily, it can seriously undermine or destroy trust in the long run.

While being a marginal topic in global bioethics, trust constitutes an essential but extremely fragile good for interpersonal relationships, social life, and global governance. The popularity of conspiracy theories on the origins of COVID-19 shows how badly lacking trust has been in the transnational settings today. Meanwhile, well-coordinated global responses to COVID-19 or the serious lack of them shows how indispensable trust is for containing the pandemic, indeed, for any global public health effort. A higher level of global governance of biosafety must be built upon trust and should aim to promote mutual trust too. Furthermore, trust can never be forced, but has to be won. The real question is thus not so much trust per se, but how to achieve trustworthiness.

In 1902, William Osler, one of the greatest physicians of modern times, delivered an address on "Chauvinism in Medicine" to the Canadian Medical Association. For Osler, chauvinism and nationalism constitutes a vicious human sin, "the great curse of humanity." $\mathrm{He}$ 
lamented that humans, physicians included, have subordinated themselves to the nation, "forgetting the higher claims of human brotherhood." Yet, he was optimistic that, due to "the liberal and friendly relationship between different nations," "the worst aspects of nationalism in medicine are disappearing." Having witnessed massive violence sanctioned by states and supported by science in the past century, we can never be as optimistic as Osler. Nevertheless, now more than ever, we need to keep upon his general universalistic moral spirit.

Long before Osler, traditional Chinese medical ethics has advocated the principle of yi nai renshu (medicine as the art of humanity). It offers a counter thesis to the exaltation of nationalism in medicine and science in the modern world. It is founded upon the fundamental Confucian universalist ideal of ren (humaneness, universal love, humanity) as well as the Confucian moral sentiment of "all people under heaven" as brothers and sisters, an ancient Eastern version of internationalism. The old Chinese designation of medicine as a means for the great Tao (Way) and as the art of humanity defines the primary goal of medicine and science not as glorifying any particular nation-state but serving the common welfare of humanity. In the age of COVID-19, to revive such an age-old Chinese ethical vision can be vital for the cause of enhancing the global oversight of biosafety and biosecurity.

\section{Conclusion}

Chinese wisdom advises that one should push aside groundless worries-like the foolish man from the state of Qi in the ancient fable who worried constantly about what he would do if the sky fell down (hence the saying Qi ren youtian - the man of Qi fears the sky falling). At the same time, this ancient wisdom tradition also encourages us to take sensible measures to prevent possible future disaster (as in the idiom wangyang bulao - it is not too late to mend the fold even after the sheep has been lost). While conspiracy theories on the origins of COVID-19 are scientifically groundless, the fear behind them is not. For the sake of the common good of humanity, developing a much more robust global governance of biosafety and biosecurity than exists at present is an urgent imperative for the international community.

\section{References}

Andersen, K.G., A. Rambaut, W. Lipkin, E.C. Holmes, and R.F. Garry. 2020. The proximal origin of SARS-CoV-2. Nature Medicine 26: 450-452.

Alibek, K., with S. Handelman. 1999. Biohazard: The chilling true story of the largest covert biological weapons program in the world. New York: Dell.

Barclay, E. 2020. The conspiracy theories about the origins of the coronavirus, debunked. Vox. Updated March 12. https:/www.vox.com/2020/3/4/21156607/how-did-thecoronavirus-get-started-china-wuhan-lab. Accessed August 5,2020 .

Brody, H., S.E. Leonard, J.-B. Nie, and P. Weindling. 2014. U.S. responses to Japanese wartime inhuman experimentation after World War II: National security and wartime exigency. Cambridge Quarterly of Healthcare Ethics 23(1): 220-230.

China Central Television (CCTV) 中国中央电视台. 2004. The Ministry of Health notifies the cause of the SARS outbreak in Anhui and pursues accountability 卫生部通报2004安徽非典 疫情原因和责任追究.July 1.http://www.cctv. com/news/china/20040701/102313.shtml.

China's State Council Information Office. 2020. Fighting COVID19: China in action (White Paper). http://english.scio.gov. cn/whitepapers/2020-06/07/content 76135269.htm.

Cyranoski, D. 2017. Inside China's pathogen lab. Nature 542: 390-391.

Devolder, K. 2015. U.S. complicity and Japan's wartime medical atrocities: Time for a response. American Journal of Bioethics 15(6): 40-49.

The Economist. 2020. Spore war: The havoc wrought by covid-19 will spark new concern over bio-weapons. April 25, 33-34.

Endicott, S., and E. Hagerman. 1998. The United States and biological warfare: Secrets from the early cold war and Korea. Bloomington: Indiana University Press.

Field, M. 2020. Experts know the new coronavirus is not a bioweapon. They disagree on whether it could have leaked from a research lab. Bulletin of the Atomic Scientists, March 30. https://thebulletin.org/2020/03/experts-know-thenew-coronavirus-is-not-a-bioweapon-they-disagree-onwhether-it-could-have-leaked-from-a-research-lab/. Accessed August 5, 2020.

Gan, N., C. Hu, and I. Watson. 2020. Beijing tightens grip over coronavirus research, amid US-China row on virus origin. CNN, April 16. https://edition.cnn.com/2020/04/12 /asia/china-coronavirus-research-restrictions-intl-hnk/index. html. Accessed August 12, 2020.

Gertz, B. 2020. Coronavirus may have originated in lab linked to China's biowarfare program. The Washington Times, January 26. https://www.washingtontimes.com/news/2020/jan/26 /coronavirus-link-to-china-biowarfare-program-possi/. Accessed August 5, 2020.

Grady, D. 2019. Deadly germ research is shut down at army lab over safety concerns. The New York Times, 5 August. https://www.nytimes.com/2019/08/05/health/germs-fortdetrick-biohazard.html. Accessed August 5, 2020.

Guillemin, J. 2005. Biological weapons: From the invention of state-sponsored programs to contemporary bioterrorism. New York: Columbia University Press. 
Guterl, F., F. Jamali, and T. O'Connor. 2020. The controversial experiments and Wuhan lab suspected of starting the coronavirus pandemic. Newsweek, 4 April. https://www. newsweek.com/controversial-wuhan-lab-experiments-thatmay-have-started-coronavirus-pandemic-1500503. Accessed August 5, 2020.

Harris, R. and J. Paxman. 2002. A higher form of killing: The secret history of gas and germ warfare. London: Arrow.

Harris, S. 2002. Factories of death: Japanese biological warfare, 1932-45, and the American cover-up, 2nd ed. New York: Routledge.

The International Scientific Commission. 1952. Report of the International Scientific Commission for the Investigation of the Facts Concerning Bacterial Warfare in Korea and China. Beijing: Foreign Languages Press.

Lederberg, J. 1999. Biological weapons: Limiting the threat. Cambridge, MA: MIT Press.

Leitenberg, M. 2016. China's false allegations of the use of biological weapons by the United States during the Korean War. Cold War International History Project, Working Paper \#78. Woodrow Wilson International Center for Scholars.

Miller, J., S. Engelberg, and W. Broad. 2002. Germs: Biological weapons and America's secret war. New York: Simon \& Schuster.

Myers, S.L. 2020. China spins tale that the U.S. Army started the coronavirus epidemic. The New York Times, March 13 (updated March 17). https://www.nytimes.com/2020/03/13 /world/asia/coronavirus-china-conspiracy-theory.html. Accessed August 5, 2020.

Mangold, T., and J. Goldberg. 1999. Plague wars: The terrifying beauty of biological warfare. New York: St. Martin's Griffin.

Moreno, J.D. 2001. Undue risk: Secret state experiments on humans. New York: Routledge.

Nie, J.-B. 2004. The West's dismissal of the Khabarovsk trial: Ideology, evidence and international bioethics. Journal of Bioethical Inquiry 1(1): 32-42.

. 2006. The United States cover-up of Japanese wartime medical atrocities: Complicity committed in the national interest and two proposals for contemporary action. American Journal of Bioethics 6(3): W21-W33.

Nie, J.-B., N. Guo, M. Selden, and A. Kleinman, eds. 2010. Japan's wartime medical atrocities: Comparative inquiries in science, history, and ethics. London: Routledge.
Nie, J.-B., T. Tsuchiya, and L. Li. 2009. Japanese doctors' experimentation, 1932-1945, and medical ethics. In The Cambridge world history of medical ethics, edited by R. Baker and L. McCullough, 589-594. New York: Cambridge University Press.

Pradhan, P., A.K. Pandey, A. Mishra, et al. 2020. Uncanny similarity of unique inserts in the 2019-nCoV spike protein to HIV-1 gp120 and Gag. BioRxiv Preprint, 31 January. https://doi.org/10.1101/2020.01.30.927871. [Not peerreviewed, withdrawn].

Preston, R. 2002. The demon in the freezer. New York: Ballantine Books.

Rogin, J. 2020. State Department cables warned of safety issues at Wuhan lab studying bat coronaviruses. Washington Post, April 14. https://www.washingtonpost.com/opinions/2020 /04/14/state-department-cables-warned-safety-issues-wuhanlab-studying-bat-coronaviruses/. Accessed August 5, 2020.

Sims, N.A. 2009. The future of biological disarmament: Strengthening the treaty ban on weapons. London: Routledge.

Wheelis, M., L. Rózsa, and M. Dando, eds. 2006. Deadly cultures: Biological weapons since 1945. Cambridge: Harvard University Press.

Xinhua News 2020. Xi stresses improving mechanism for major epidemic prevention, control. Xinhua Net, February 15. http://www.xinhuanet.com/english/2020-02/15 /c_138784656.htm. Accessed August 5, 2020.

- 2018. The First P4 Laboratory in China is officially in operation中国首个P4实验室正式运行. Xinhua Net, January 5. http://www.xinhuanet.com/politics/2018-01/05 /c_129783861.htm. Accessed August 5, 2020.

Yang, Y.-J., and Y.-H. Tam 2018. Unit 731: Laboratory of the devil, Auschwitz of the East (Japanese biological warfare in China 1933-45). UK: Fonthill Media.

Yuan, Z. 2019. Current status and future challenges of high-level biosafety laboratories in China. Journal of Biosafety and Biosecurity 1(2): 123-127.

Publisher's note Springer Nature remains neutral with regard to jurisdictional claims in published maps and institutional affiliations. 